\title{
Bishops, Boozers, Brethren and Burkas: Towards a Cartoon History of Religion in New Zealand
}

MIKE GRIMSHAW

Neither let archbishops, bishops, nor any officers of the church plead sanctuary. History answers from the pencil-point. The sense of proportion is a divine attribute. No close season for popes or parsons, please. I confidently expect to find caricaturists in heaven.

David Low ${ }^{1}$

In his 1941 centennial survey of New Zealand, Oliver Duff observed, 'We are not Puritan enough to take our pleasures sadly, but we take them very seriously'. ${ }^{2}$ Duff's comments offer a useful starting point for the investigation of cartoons in New Zealand history. Cartoons - that is, editorial cartoons - are a serious pleasure, a type of puritanical corruption of a Protestant sensibility. They are an act of protest, commonplace in the main, but expressed in such a manner as to make the commonplace interesting. Ingvild Saelifd Gilhus, in her study on laughter in the history of religion, refers to Bakhtin's description of carnival laughter as virtually an alternative to religion. Carnival laughter is 'cathartic and salvific, an expression of rebellion aimed at the religious authorities and their institutions, past and present'. ${ }^{3}$ This essay seeks to explore the ways that the carnivalistic humour of the cartoon has represented religion in New Zealand over the past 150 years, aiming to lay the ground work for developing a cartoon history of religion in our society.

New Zealand is an intriguing place to study religion and teach Religious Studies (the difference between these two activities is a familiar tension for our discipline). In the latest census (2006) around half the total population of four million either stated that they had 'no religion' or 'declined to state' any religious identity. ${ }^{4}$ Furthermore, New Zealand, while never having professed or legislated a state religion, has recently adopted a politicallydriven Statement of Religious Diversity administered at a national level by the Department of Ethnic Affairs. Such a location makes it clear that in a culture that is officially secular, religion is primarily regarded as an ethnic issue: a cultural activity predominantly undertaken by non-European immigrants (statistics code for 'non-white') which includes Muslim, Buddhist, Hindu 
and Sikh populations, as well as 'non-white' Protestants and Catholics, the indigenous Maori population (incorporating Protestants, Catholics, Mormons, forms of Maori Christianity ${ }^{5}$ and traditional beliefs and practices) and the large Pacific Island population (Protestant, Catholic and Mormon) who have been a significant part of New Zealand urban life since the 1960s. In such a context scholars of religion become attuned to rich ironies. Theology is only studied in two state universities (Otago in the South Island and Auckland in the North). ${ }^{6}$ These theology departments have emerged from, and are strongly linked to, seminary and confessional traditions that are, within the wider secularity of New Zealand life and society, primarily theologically sectarian and socially conservative. In short this country is the embodiment of a modern society ${ }^{7}$ after religion (at the very least, after 'Christian society' and 'Christian culture'), a society increasingly indifferent to religion. Yet New Zealand is also experiencing a growth in a sectarian, religiously and socially conservative rump. While the numbers of non-religious continue to grow, those who do express a religious identity now primarily identify with the more evangelical and Pentecostal forms of Christianity, and also, with a resurgent, conservative Catholicism ${ }^{8}$. Furthermore, half of the population of four million who signalled a religious identity in the last census, did so within 123 different religious identities. This may be post-modern pluralism, yet it is lived and experienced within a wider modernist 'end of religion'. In such a context, it is reasonable to expect that religion would exist as a sideline from mainstream daily life. For most people this is indeed the case. However, there is evidence, not usually noted by scholars, that perceptions are changing in the context of the recent rise of conservative religion.

It was sociological orthodoxy for thirty years, from the 1960s, that religion was on the decline in the west. The much-vaunted secularization thesis of Peter Berger and like-minded sociologists found a ready audience amongst liberals and secularists in modern Western societies. Yet Berger recanted his thesis in $1999^{9}$ and events of the past decade, especially following 'September 11', have forced a reassessment - the death of religion has been exaggerated.

This return of religion can also be noted in New Zealand editorial cartoons. The religious cartoon strongly reappeared in the mid 1970s, appeared with increasing frequency in the 1980s and from the mid-1990s it was not unusual to see a cartoon critiquing religion. Of course, religion is a notoriously difficult and slippery term to define..$^{10}$ As scholars of religion are well aware, there is no singular, agreed upon definition of religion, but it is apparent that religion as a concept arose within a Western Christian environment and then was 'exported' and imposed on the wider world and other cultures. ${ }^{11}$ By itself, religion exists primarily as a descriptive and comparative term that is, as Jonathan Z. Smith suggests, a 'second-order 
abstraction". ${ }^{2}$ Smith reminds us "the academic study of religion is a child of the Enlightenment', ${ }^{13}$ a comment which is further amplified by Charles Winquist's stating 'the generic concept of religion is not innocent of the genealogy of its origination in the Enlightenment'. ${ }^{14}$ Likewise, Graham Ward has argued in True Religion for the need for a genealogy of religion to help us understand not only 'the trajectory of the history of the social production of religion' but also the 'discursive practices' closely linked to religion and antithetical to 'the changing understanding of religion.'.

In contrast, in the New Zealand context religion is a term often used, but not often defined or properly understood. Religion is taken to include not only traditional forms of institutional Christianity, but also varying forms of Maori religion, manifold spiritualities and the New Age, and increasingly Islam. In effect, religion is a catch-all term that New Zealanders have tended to define themselves either for or against. It is most often associated with institutional Christianity but also extended, in popular vernacular, to cultural expressions of enthusiasm, most notably the claim that rugby is New Zealand's religion. This paper is concerned with the expressions of 'religion' linked, firstly, to institutional Christianity and latterly to the rise of New Age and postmodern spiritualities and, lastly, to the impact of militant Islam. The cartoons exist within a culture of popular representation, discussion, controversy and caricature regarding religion. Therefore, such cartoons conform to and confirm popular beliefs and expression as to what 'religion' is: primarily Christian and institutional, sometimes New Age and Islam. The latter two are often presented as even more irrational and problematic than Christianity.

Religion is therefore presented both as something reacted to, and also as something understood as defined and definable within popular opinion. What needs to be grasped is that religion is presented in the cartoons primarily as a problem, an issue to overcome, or a type of intruder into the public realm from the private sphere - a separation that in the West can be traced back to the sixteenth century and the Protestant distinction of the twin spheres. Yet conversely it could be argued that New Zealand only really becomes secular when it does view religion as a public issue and problem. For, as Russell T. McCutcheon argues, the secular and the religious are 'co-dependent, portable discursive markers' ${ }^{16}$ : without each other they fail to exist or have independent meaning. Therefore, the growth of New Zealand as a truly secular society can be traced to the increasing confrontation with religion as it enters and presents itself within the public realm. For only when this intrusion is seen and presented as an issue, and perhaps most importantly, only when the Protestant intrusion is seen as an issue, is the society properly secular. This is because the response to a Protestant intrusion makes explicit the religious-secular divide in Western 
societies that have traditionally been more opposed to Catholic intrusions into public space and often turned a blind eye to Protestant actions and claims.

The editorial cartoonist as a type of corrupt puritan engaged in protest can be traced to Martin Luther's use of cartoons against his opponents, for example representing the Pope and his priests as wallowing swine, or the Pope as the Whore of Babylon. These woodcut polemical cartoons drew on a German tradition of the illustrated broadsheet and became a virulent religious and political weapon in the hands of Luther and his fellow Protestant reformers. ${ }^{17}$ For cartoons are more than just pictures or images, more than just a representation upon a page; they are in fact a type of visual anguish. The famous New Zealand cartoonist Sir Gordon Minhinnick described them as 'an act of protest', as 'a negative conception . . . usually against some thing or somebody' ${ }^{18}$ Cartoons, especially editorial cartoons, are therefore the language of protest, the language, often, of a type of carnivalistic puritan opposition to that which challenges the sensibilities of the cartoonists and their intended audience. We can see this in an ancient anti-Christian cartoon graffittied on the wall of the Palatine in Rome. The roughly inscribed image presents a crucified figure with the head of an ass or donkey. There is another figure presented to the right with an arm up stretched in homage. Beneath this are scratched words translated as "Alexamenos worships his god'. ${ }^{19}$ The meaning is clear, existing through the interplay of text and image: in worshipping their ass-headed god, Christians themselves are asses. From a theological viewpoint this could be read as what Paul referred to in Galatians 5:11 as 'the offence of the crosses'. In crossing time and space to this contemporary discussion of New Zealand religious cartoons, we are struck by a remarkable consistency. Presented in the public space of the editorial page of a newspaper, the cartoon becomes a means whereby the offence of the cross, or more often, the offence of particular Christian claims, actions and personalities becomes subject to public critique, ridicule and challenge. 'Alexamenos' finds little public support in New Zealand when he intrudes into public life. We can understand the ancient cartoon because cartoons are, as Ed Ross notes, enthymemes - that is rhetorical exercises which depend on the audience participating in the argument by utilizing its pre-existing knowledge..$^{20}$ In this particular example, there is the expectation that those viewing the graffiti were able to understand the reference of the common image of the crucified man to the specific reference of Christianity. More so, beyond the symbol of the crucifixion, we can understand, across the centuries, the contemporary sentiment that Christians were believed to be foolish asses.

An important element of the editorial cartoon is that it demands that a choice be made, that a particular position be expressed. However, this 
choice is not only that of the cartoonist. The cartoon also, most importantly, demands the audience makes a choice whereby, as Richard Reeves, writing on American political cartoons puts it: 'you get it or you don't; you like it or you hate it'. ${ }^{21}$ The important point here is the understanding that to 'get it', that is to understand it, does not necessarily mean that you will like it; in fact 'getting it' may mean you hate it. The success of the cartoon is therefore achieved in its being understood, but not necessarily in its being liked or agreed with. In acting as editorial comment, such cartoons as discussed in this essay must find a degree of coherence with their audience, for a successful cartoon may not be necessarily liked or appreciated but it will be understood by the majority of its audience. A cartoon that becomes too Gnostic in its expression fails in its prime task of the accessible communication of an opinion reinforced by 'contemporary assumptions and prejudices'. ${ }^{22}$ This is not to say that cartoons are an essentially conservative expression, but rather that they operate in what cartoonist Dylan Horrocks terms 'a range of dialects' - some are 'concentrated in a particular place and others are located around a particular sensibility'. ${ }^{23}$ John Geipel, in his history of the cartoon went so far as to term them 'the slang of graphic art' in that 'they tend to rely for their impact upon spontaneity, playfulness, popular imagery and often deliberate vulgarity'. ${ }^{24}$ Here, we can make reference back to carnivalistic laughter.

The cartoon as we understand it today, as distinct from the European tradition of the caricature, occurred in the pages of Punch, the London magazine established in 1841 on the model of the French weekly satirical paper Charivari. Up until 1843 the term cartoon, which is derived from the Italian cartone, meaning a large sheet of paper, referred to the line drawings used as a preliminary lay out. In that year, in Punch, the artist John Leech did a series of drawings lampooning an exhibition of the cartoons (in the original sense) for the frescoes of the House of Commons. The success of Leech's work meant the name 'cartoon' stuck for a work of public criticism expressed in a combination of images and words. It is important however to further clarify what is meant by cartoon in this discussion. While cartoon has become a general term, the cartoon may cover a wider series of representations and formats, from 'the funny pages' with their emphasis on humour and amusement, to comics and comic books, through to the graphic novel, and also the 'moving' cartoons of television and cinema. All of these possibilities include both amusing/humorous and/or satirical combinations of image and text. The cartoons under discussion actually fall into a subsection called caricature. While other forms of cartoon may be 'value-neutral', a caricature is negative and rebuking. It 'pertains to grotesque or ludicrous representation of scorn or ridicule of human vices or follies and exaggeration of their most characteristic features by means of graphic images'. ${ }^{25}$ 
Therefore what are often called cartoons are more specifically types of caricature, and most religious cartoons further fall into the designation of political caricatures, rather than social caricatures, because they are concerned with the interplay of religion and 'the distribution of power in society'. ${ }^{26}$ Furthermore, as religion becomes active in the political sphere it becomes the target of political satire and caricature, while at the same time there is a corresponding fall-off in the social satirization of religion that most often takes the form of ridiculing ineffectual, bumbling clergy unsuited to the contemporary world. Such clergy are presented as of no importance or threat to the political fabric of society. Once the political satirization of religion occurs, there is little social satire. The question remains as to whether this is due to a fading of the social impact and role of religion, or whether the political intrusion of religion takes precedence in public responses and opinions.

New Zealand has a rich cartoon history, from the early days modelled on Punch through to today's polyglot influences expressed in various cartoon dialects. New Zealand has an international reputation as a source of cartoonists who have made an impact, the foremost being David Low, but as John Lent notes, New Zealand cartoonists have had successful careers in England, Australia, Canada and the United States. ${ }^{27}$ Indeed David Low has commented that New Zealand's two most important exports were mutton and cartoonists. ${ }^{28}$ As a source of historical scholarship, cartoons have gained legitimacy since Thomas Kemnitz's essay 'The Cartoon as Historical Source' was published in the Journal of Interdisciplinary History in 1973. Kemnitz begins by quoting from M.H. Spielmann who, in Cartoons from Punch (1906) described cartoons as 'contemporary history for the use and information of future historians'. As Kemnitz is careful to note, the information cartoons offer is most often that of 'public opinion and popular attitudes' 29 that is, what we can term socio-cultural history, a form of cultural studies.

While the collected cartoons of artists such as Minhinnick, Sid Scales, Eric Heath and Neville Lodge all appeared with periodic regularity, for most of the twentieth century there was no comprehensive overview using New Zealand cartoons as a 'historical source'. This changed with the appearance in 1980 of Ian F. Grant's groundbreaking The Unauthorized Version. A Cartoon History of New Zealand. ${ }^{30}$ This text presented New Zealanders with a new version of their history: a visual history, a carnivalistic history that also offered an often challenging and disturbing look into national and historical beliefs, actions, stereotypes and assumptions. This was not the history of their country that most New Zealanders had studied at school, for much of the content had been, if not exactly hidden, then often conveniently overlooked in the official telling of the nation's story. Yet this 
was a history that most of us recognized: a lived history, a visual history, a snap-shot of public sentiment presented to us each day in our newspapers. This carnivalistic history also challenged many of our official self-definitions as a tolerant and progressive society. For the popular sentiment presented in these cartoons was often bitter, resentful, puritan, racist, sexist and suspicious of difference and authority. It celebrated yet belittled both the powerful and the champions of the underdog.

A direct result of Grant's book was the establishment of the New Zealand Cartoon Archive (http://www.cartoons.org.nz/) housed in the Alexander Turnbull library. This has been responsible for many exhibitions and books presenting different collections and aspects of New Zealand's cartoon history to the wider public. While topics such as trans-Tasman relations, rugby, Premiers and Prime Ministers, and the changing role of women have all been subject to exhibition and printed collections ${ }^{31}$, there are many more topics that could illuminate aspects of New Zealand society and history ${ }^{32}-$ including of course, cartoons showing the role of, and response to, religion in New Zealand.

The public sentiments that our cartoonists represented and presented (in what is a dialectical relationship) is the basis for what Neil Cohn in his essay 'Un-defining Comics' ${ }^{33}$ calls a type of revisionist scholarship. I would further argue that a cartoon history of religion in New Zealand allows a new type of double revisionism, not only of the marginalized source of cartoons - especially in religious history - but also of the marginalized study of religion in New Zealand society and history.

Grant's cartoon history of New Zealand followed a traditional understanding of New Zealand history at that time, in which religion was a marginal activity, especially after early missionary days. Elements of this attitude are still with us, and recent revision stressing the importance of religion has yet to embrace cultural studies in general and cartoons in particular. Yet the proliferation of cartoons on religion in New Zealand offers a contrasting point of access to the various ways we have responded to religion, ${ }^{34}$ an approach informed by the great German-American theologian Paul Tillich who stated 'As religion is the substance of culture, so culture is the form of religion'. ${ }^{35}$ A cartoon history of religion in New Zealand will demonstrate that we have been concerned with religion and religious ideas and influences from our earliest days as a nation. In fact our national identity has often been expressed as the overcoming and negation of religion. Yet while we as a people, as a society, and perhaps most often as scholars and intellectuals may not necessarily like or really understand religion, we must recognize its potent influence. Many have a limited but significant engagement with religion, either 'believing but not belonging' (orig. 1993 ${ }^{36}$ ) or belonging but not necessarily believing. Both are forms of religion as 
culture, and both involve a strong degree of critique. Both of these attitudes, I argue, need to exist for religious cartoons to flourish.

In considering New Zealand cartoons on religion certain themes predominate. These can be grouped under several headings.

\section{The problem of political clergy}

As part of the colonial vision of a 'better Britain', nineteenth-century New Zealand settlers established a number of newspapers, journals and magazines that consciously replicated the media of Victorian Britain. ${ }^{37}$ These included several antipodean versions of Punch in Auckland, Wellington, Taranaki, Christchurch and Dunedin. While these were short-lived and of varying quality, they did include cartoons addressing matters of local interest and concern, and this included religion. In the pages of both the Taranaki and Auckland Punch, there are several cartoons from the 1860s that attack the involvement of missionaries and evangelical lobby groups in colonial politics. ${ }^{38}$ The common theme, presented from a settler viewpoint was that missionaries, in their involvement in politics, are duplicitous and race traitors. Cartoons from this period are blunt in their rejection of political religion. In a woodcut cartoon from Taranaki Punch (Figure 1), the conversation is between Governor Thomas Gore Browne (on the left) and Bishop George Augustus Selwyn (on the right). As head of what was termed 'the Church party' Selwyn lead the opposition to the colonial government's actions during the Taranaki wars of $1860-61$. What is important to note in this cartoon is that behind the Bishop lurks the figure of the devil. This references Giotto's fresco 'The pact of Judas' wherein Judas, in receiving his 30 pieces of silver for betraying Jesus ${ }^{39}$ is shadowed by Satan. The implication of the cartoon is clear - the man of god has sold his allegiance for self-interest. Another cartoon from Taranaki Punch pictures Church Party firebrand, Archdeacon Octavias Hadfield of Otaki dreaming of Britannia paying homage to a Maori king. ${ }^{40}$ Critiquing British support for Maori, a cartoon from Auckland Punch pictures a meeting at the London evangelical centre of Exeter Hall. Here both the speaker and his audience are shedding tears for Maori under a sign proclaiming: 'Down with the colonists. Long live our darling cannibals'. ${ }^{41}$ Similar cartoons commonly castigate the Aboriginal Protection Society for appearing to condone the murder of settlers. In all these cartoons there is a strong sense that the involvement of religion in politics is working against the interests of settlers.

These cartoons set the tone for the next 150 years whereby a consistent theme in New Zealand cartoons is that religion and politics cannot and should not mix in this new society. For while the churches might claim that they are involved in politics for a greater good, and in response to the gospel, the cartoonists' view is more often that churches are hypocrites 


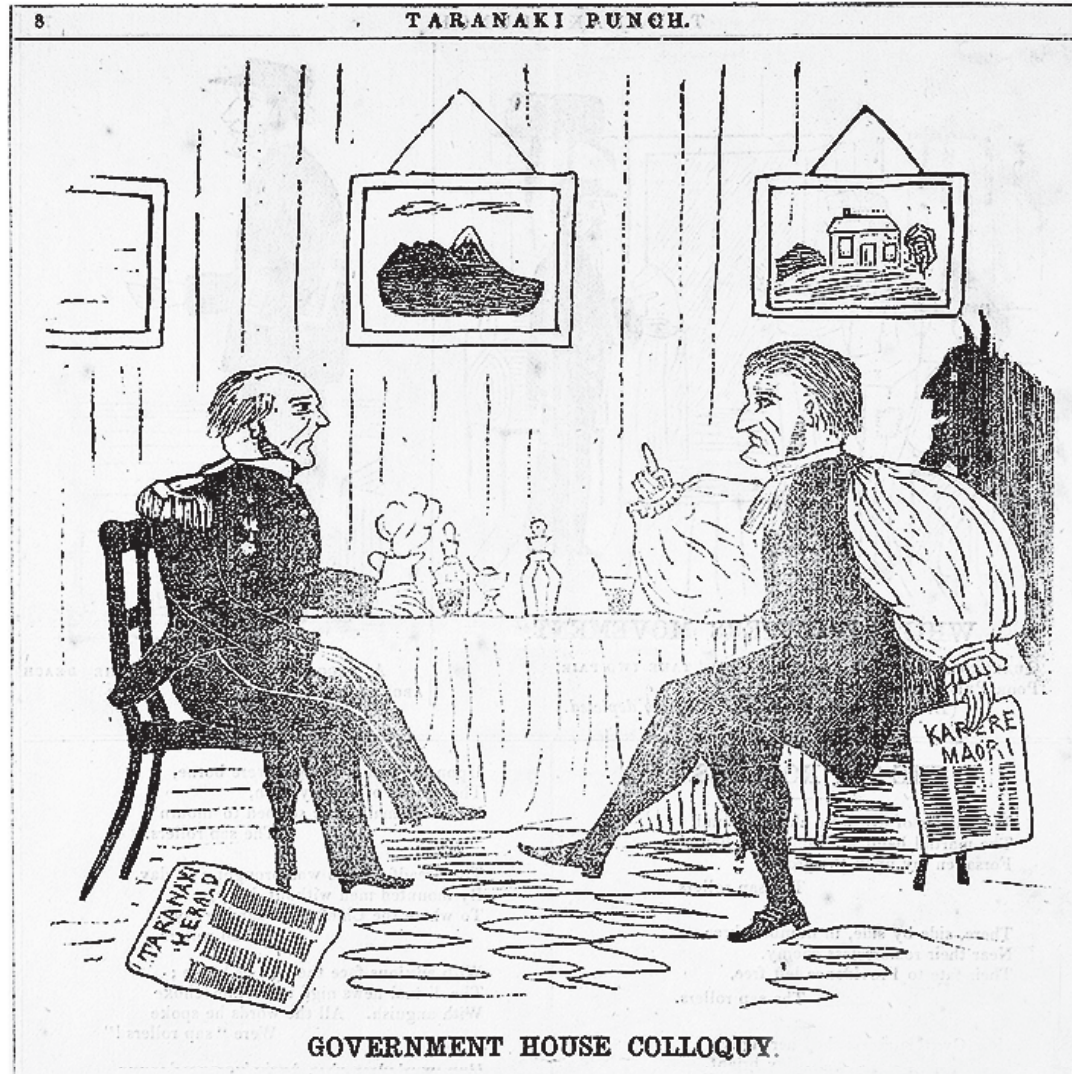

B- P S-N, - I admit, your Bxcellency, that these misquided natives (acting, no doubt, under Europern influence) have opposed your arms, and have unfortunately, and probably in self-defence shot 3 few people who foulishiy straycd too far from the town, and also made some mistakes respecting the rights of property, but, after all, they are but semi-barbarians, and it is your duty to

G-_ B B-B.-Of course; I understand! Let them return to their homes in pesce; withdraw my troops, and throw the settlers"on Maori protection; eh!

$\mathrm{B}-\mathrm{P} \mathrm{S}-\mathrm{x}-\mathrm{-Precisely}$ so $\mathrm{with}$ the addition of paying them for the disputed land and the expenses they have been put to during the war.

$G-B$

Figure 1: Government House Colloquy, Taranaki Punch, Vol. 1, no.11, 13 March 1861. ARC2002-538, Collection of Puke Ariki, New Plymouth.

"B-p S-n - I admit, your Excellency, that these misguided natives (acting, no doubt, under European influence) have opposed your arms, and have unfortunately and probably in self-defence shot a few people who foolishly strayed too far from the towns, and also made some mistakes respecting the rights of property, but after all, they are but semi-barbarians, and it is your duty to -

$\mathrm{G}-\mathrm{r} \mathrm{B}-\mathrm{e}-$, Of course! I understand! Let them return to their homes in peace, withdraw my troops, and throw the settlers on Maori protection; eh!

$\mathrm{B}-\mathrm{p} \mathrm{S}-\mathrm{n}-$, Precisely so! with the addition of paying them for the disputed land and the expenses they have been put to during the war.

G-r B-e -, l'll see them d-d first!" 


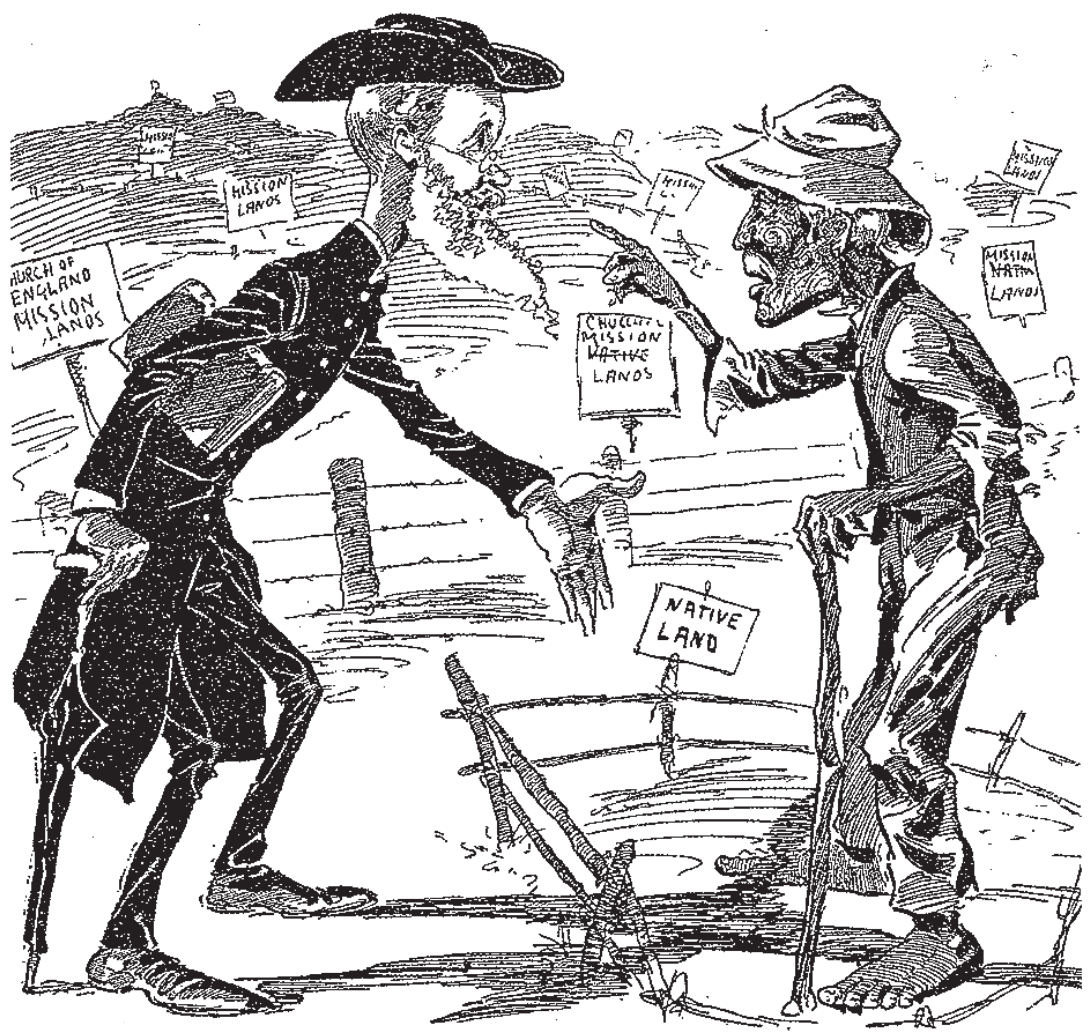

THE CHURCH HAS GOT ITS SHARE.

CLARKE (at the Anglican Synod): If something is not done to prevent the reckless sale of land by the Maoris, in less than a generation they will be landless and a burden to the colonists. THE LANDLESS MAORI: Taihoa! But where has the best of our land gone? How much of it have the missionaries got? How much has the Church got? You people have done your share, too, to make us landless.

Figure 2: 'The Church has got its Share', William Blomfield, New Zealand Observer and Freelance, 11 December 1897, p.1. ATL A-312-6-025

seeking worldly power and goods - such as Bloomfield's 1897 critique of Anglican double standards regarding the sale of Maori land (Figure 2). Such concerns continued into the twenty-first century. The rise of Destiny Church under (self-appointed) Bishop Brian Tamaki resulted in considerable opposition from New Zealand cartoonists. Triggered primarily by the infamous 'Enough is Enough' march on Parliament (23 August 2004) to oppose civil unions, Tamaki and Destiny came under considerable criticism, all focused on ridiculing his attempts to give a public and political voice and role to his church and wider Pentecostal Christianity (see Figure 3). The 


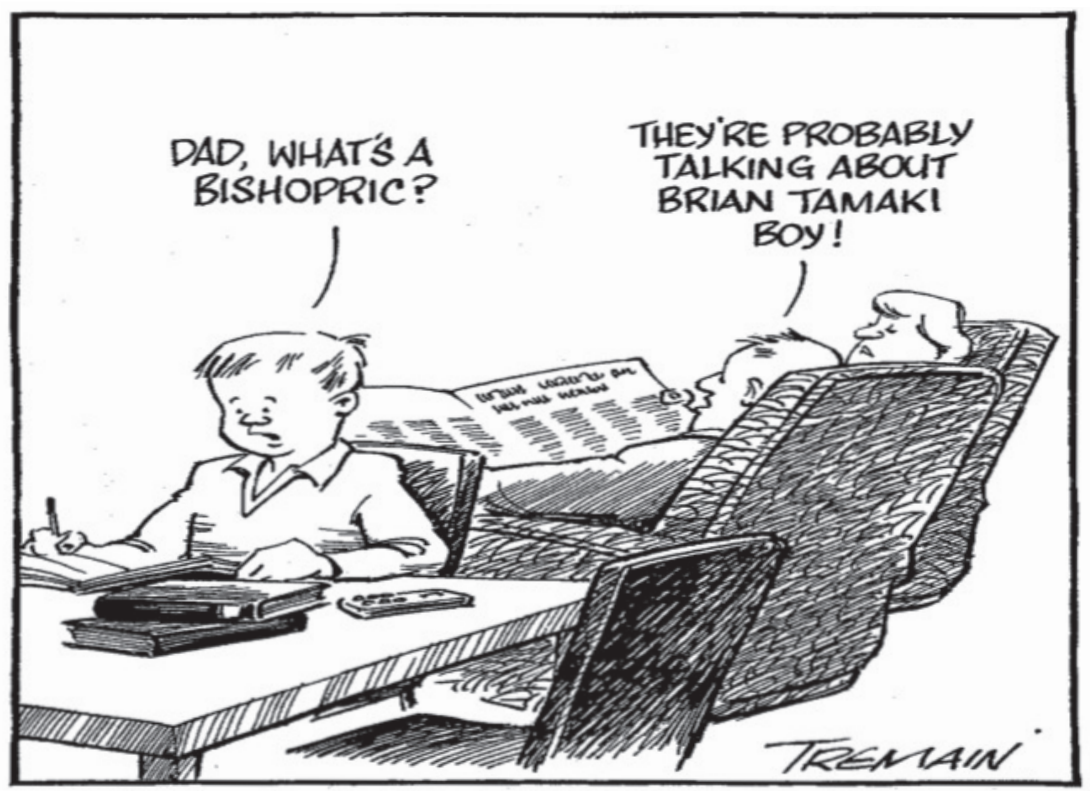

Figure 3: Garrick Tremain, Cartoons, Vol.15, Christchurch, 2006.

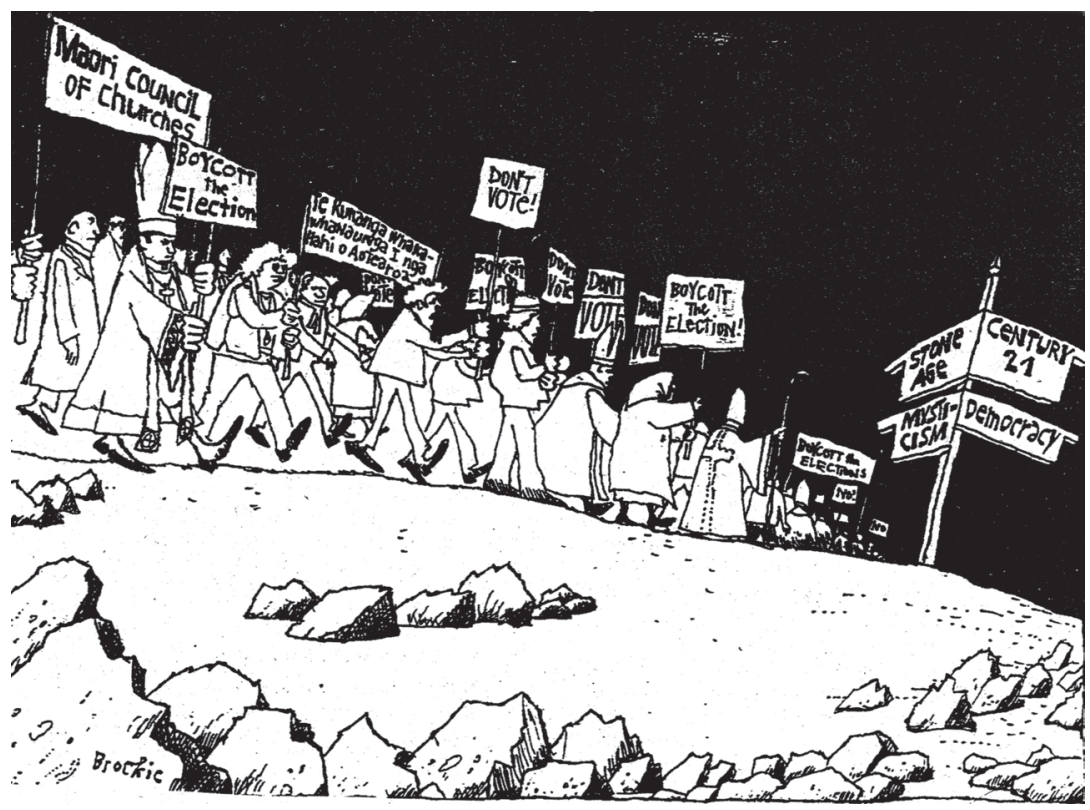

Figure 4: Bob Brockie, National Business Review, 14 September 1990. 
criticism continued following Tamaki's opposition to the National Statement on Religious Diversity and his calls for New Zealand to identify as a Christian nation, the launch of various political parties and the revelation of pledges of loyalty to Tamaki by church members. Tamaki's actions provided a rich target for cartoonists who portrayed him as a mix of televangelist and cult leader. What is interesting is that the critiques were focused on the religious aspects of Tamaki and Destiny, not on the overwhelmingly Maori and Pacific makeup of his church. Destiny was presented as a claim and issue of religious politics, not of racial or cultural politics. It is interesting to consider that the ongoing political role of the Ratana church does not attract similar critique. In fact one has to go back to the 1990 general election and the call from church leaders, both Maori and some Pakeha, for Maori to boycott the elections, to uncover a critique of combined racial and religious politics (Figure 4).

The revelation of links between the leader of the National Party Don Brasch and the Exclusive Brethren in the lead up to the 2005 general election also proved a popular target for cartoonists. Here again strong disapproval was expressed, mocking both the Brethren and Brasch. The critiques were equally shared between disapproval of a major party leader consorting with a sectarian and secretive religious group, and of the involvement of that

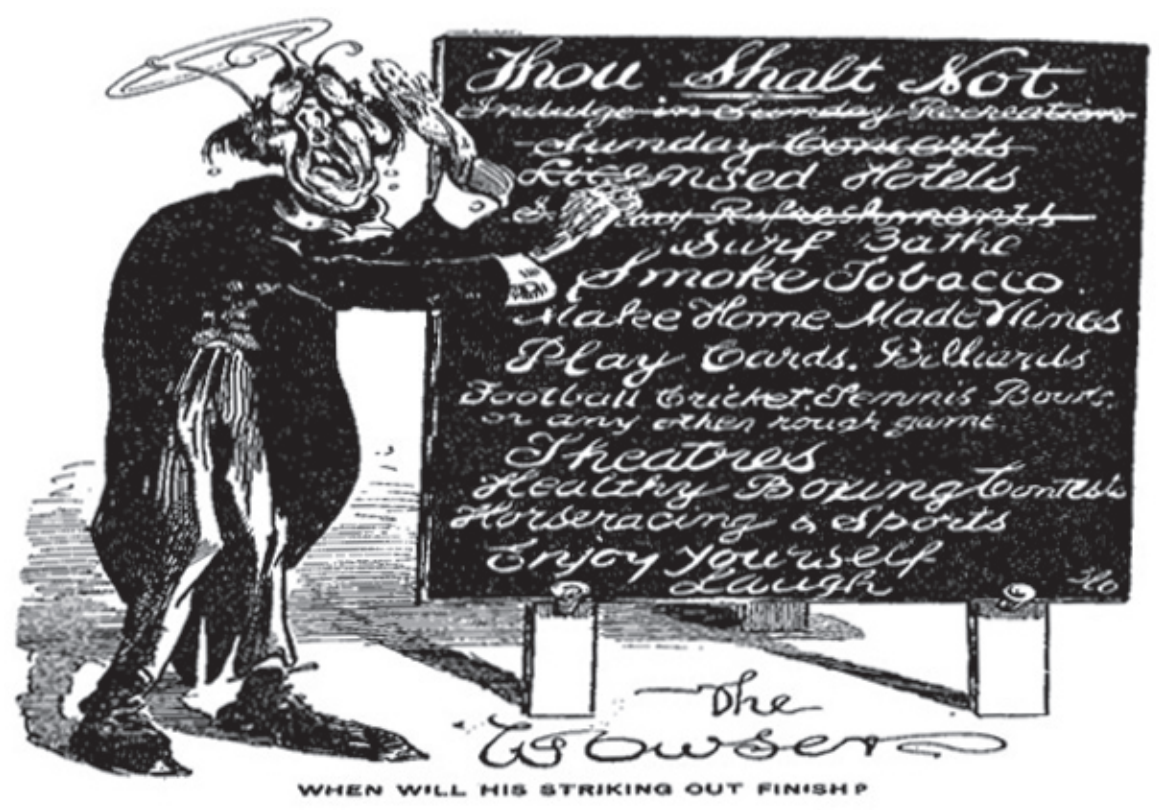

Figure 5: 'When Will His Striking Out Finish?', W. Blomfield, Observer, 1911. 


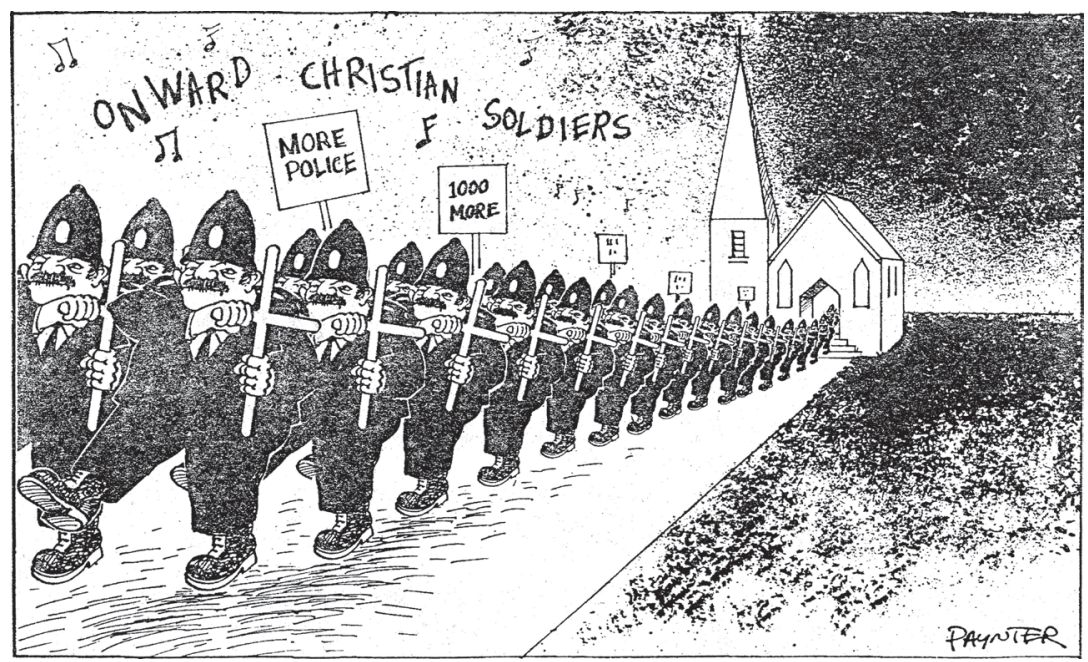

Figure 6: Bill Paynter, National Business Review, 6 August 1987.

group in national politics, when its members do not vote. This continued the consistent theme, dating back over 150 years, that in New Zealand religion and politics should not mix.

\section{The religious as problematic moralists}

Associated with the first theme, and recently expressed in the opposition to both Destiny and the Exclusive Brethren is the second dominant theme: religion and issues of private lives and public morality. From the late nineteenth century, clergy are often presented as more concerned with moral codes and prohibitions than with the real lives, pleasures and rights of the wider population. An extension of discussions on temperance, the figure of the Christian kill-joy or wowser makes an appearance (Figure 5) at the beginning of the twentieth century, threatening to close down all avenues of pleasure and turn the country into a puritan theocracy.

Conservative Christian values are also attacked in response to the church's opposition to divorce, abortion and later, homosexuality. In the 1980s the fact that senior police officials were often members of conservative Christian churches opposed to homosexual law reform was strongly critiqued by cartoonists, perhaps most notably in Bill Paynter's 1987 cartoon picturing an army of Christian police marching out a church singing 'Onward Christian Soldiers' (Figure 6). Cartoonists have tended to take the side of social and moral change, even when, as in Paynter's case as cartoonist for the National Business Review, the readership of their papers might have dissenting views. Yet while the role of cartoonists is to provoke a response, and often a 
reassessment of the issue under debate, they must also be able to tap into the underlying ethos of society and especially their particular readership. The cartoons that began to regularly appear from the 1970s challenging the churches' position on divorce, abortion and homosexuality, represent a wider societal shift. More recently, the perceived lack of response of the Catholic church, in particular, to cases and allegations of child abuse have drawn strong disapproval from cartoonists. The media's increasing portrayal of the church, and Christians more generally, as intolerant bigots, represents a significant change in New Zealand's long-vaunted secularism which had tended, for half a century, to only attack the marginal, sectarian expressions of Christianity. While secularism has long advocated separate spheres - a public secularity and private religiosity - the intrusion of the churches into issues of individual rights and identities created a growing secular opposition to Christianity. The collapse of mainstream liberal Christianity in the wake of the Geering controversy in the late 1960s, ${ }^{42}$ the rise of American style fundamentalism and Pentecostalism, ${ }^{43}$ and the increasing political and social resurgence of the global Catholic church under Popes John Paul II and Benedict XVI, have all contributed to a situation whereby secular society finds itself in increasing opposition to forms of conservative Christianity.

\section{The critique from Tomorrow}

Until the 1970s, while there was consistent social satire of clergy, often inline with the types of cartoons found in the English Punch, most was fairly benign. An important exception occurred in the 1930s, in the pages of Tomorrow, a leftwing magazine of politics, society and (often overlooked), poetry and literature. ${ }^{44}$ Tomorrow was driven by the eclectic vision and editorship of Kennaway Henderson, supported by H.Winston Rhodes, Frederick Sinclaire and especially, the poet and printer Denis Glover. Henderson was probably the least political of the founding committee, described by Rhodes as "vaguely . . . a humanitarian with a radical bias' ${ }^{45}$ and 'an armchair socialist'. ${ }^{46}$ Born in London in 1879 , Kennaway ${ }^{47}$ could be best characterized as an Edwardian ${ }^{48}$ artistic dilettante; one of those figures drifting around the margins of the artistic and literary world, turning his hand to various projects when circumstance required. Impressed by Tolstoy's writings $^{49}$ and consequently passionately opposed to what he saw as 'the hypocrisy of state, church and vested interest,${ }^{50}$ he refused to serve when called up for military service in 1918, was court-martialed and sentenced to nine-months hard labour. On release he was soon rearrested, sentenced to a further two years of hard labour, finally being freed in November $1920 .^{51}$ After a period in Auckland where, through Alan Mulgan, ${ }^{52}$ he met his future collaborator Frederick Sinclaire, Kennaway left for Sydney where he eked out a life as a cartoonist and artist. Here he met and influenced the young 
David Low ${ }^{53}$ and inspired by the journal The New Age, decided to attempt an antipodean version.

On returning to Christchurch, Kennaway gathered an editorial committee of Frederick Sinclaire, Professor of English at Canterbury University College (also an ex-Unitarian minister and past leader in Sydney of the Free Religious Fellowship) and the young Marxist, H.Winston Rhodes, the Canterbury University College literary scholar and past pupil of Sinclaire. If Henderson was an 'Edwardian radical', and Rhodes possessed strongly Marxist sympathies, Sinclaire was 'the voice of an uncompromising liberal'. ${ }^{54}$ They were soon joined in 1935 by Denis Glover and, as business manager, Bruce Souter of the Public Trust Office. Glover's boundless enthusiasm was tied to

Kennaway's passionate disdain for all that smacked of bourgeois respectability. In 1940 Glover wrote what he hoped was still

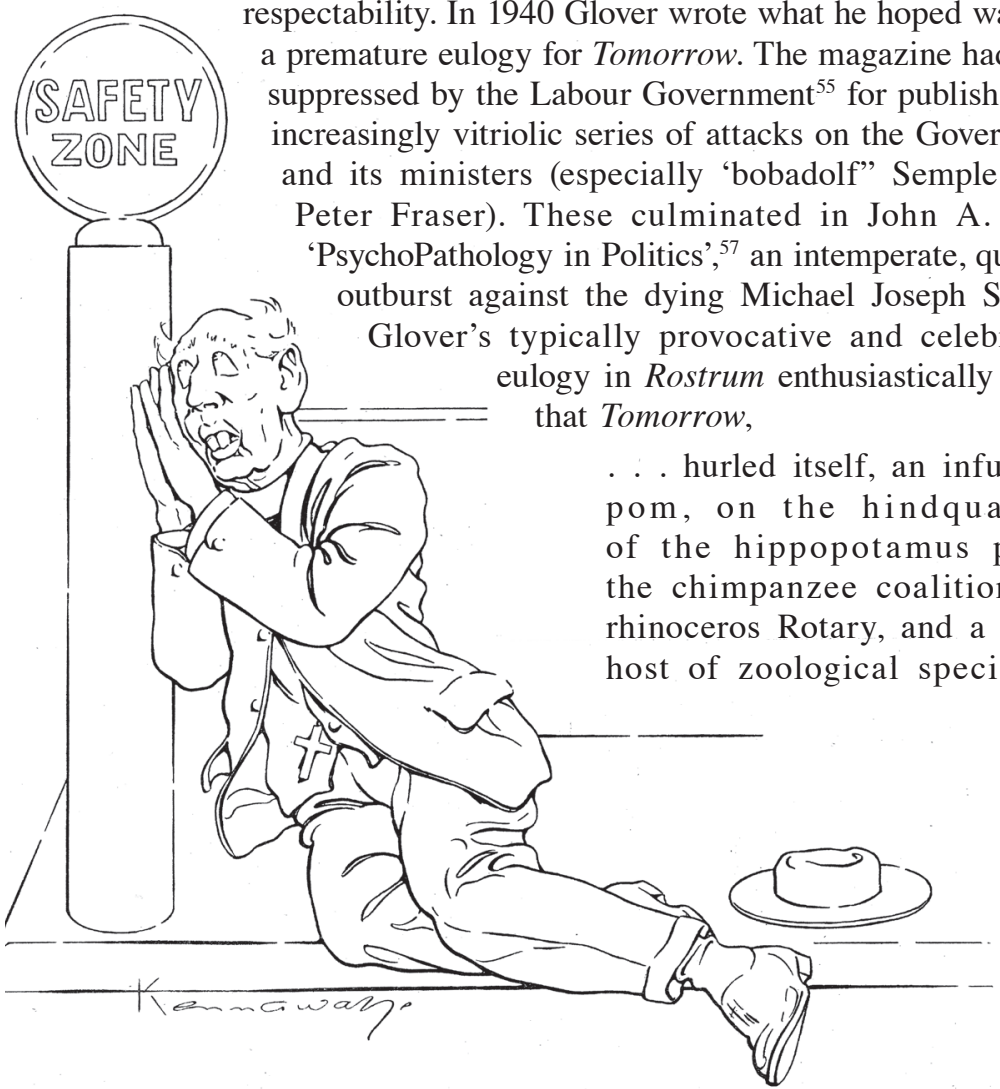

AN OUTLINE OF THE POSITION-SAFETY FIRST

Figure 7: "An Outline of the Position - Safety First", Kennaway, Tomorrow, 9 December 1936, p.74. 
It attacked institutions because institutions become persecutions. It attacked everything in which it saw the real or fancied shadow of a threat to freedom. ${ }^{58}$

Glover's eulogy is crucial for understanding Kennaway's cartoons - and their articulation of a new perspective against religion as an enemy of freedom. For Kennaway's cartoons in Tomorrow attacked both the church as an institution and its clergy as variously crypto-fascists, lazy, corrupt, timid and self-interested (Figure 7), materialistic and generally unsuited to contemporary life - all themes that, over the next 70 years steadily gained widespread and mainstream acceptance. Civil War Spain became a central focus for Tomorrow with poems, articles and cartoons all expressing a Popular Front ethos, highly critical of fascism and the Catholic Church. Another world war was seen as increasingly inevitable, and the Christian Church's culpability (through supporting Franco and opposing leftwing and communist opposition to fascism) roundly condemned. In the pages of Tomorrow, God, if not dead, was notably absent - or uncaring. I have focused on Tomorrow because it is a part of our cultural history that few are aware of. Yet it counted many contemporary and future politicians, academics and civil servants amongst its contributors - and readers. The local criticism of religion was located within a wider arena of global politics and made explicit the critique and rejection of religion as part of a progressive, leftwing sensibility in this country.

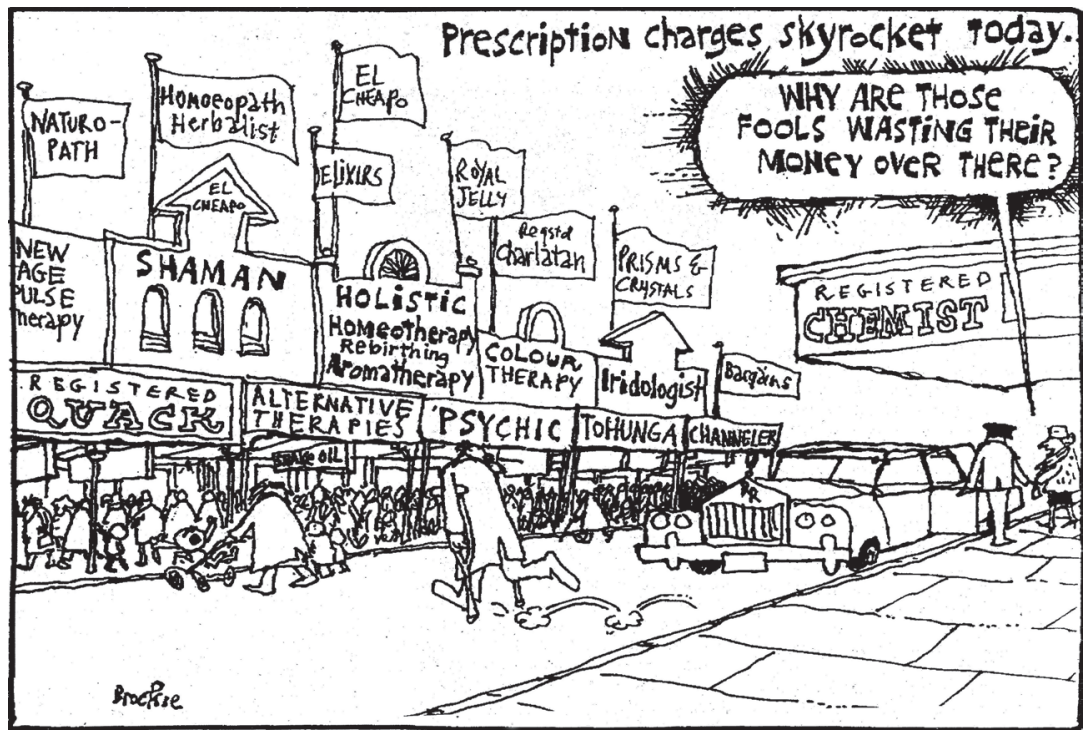

Figure 8: Bob Brockie, National Business Review, 1 February 1991. 


\section{Godzone - without god}

Over the ensuing half-century the dislocation of religion and New Zealand life became central and widened from the political left into the mainstream of society. For this is Godzone without god - or at least a society where God and God's representatives are kept at arm's-length. Particularly astringent has been the work of Bob Brockie in the National Business Review. Brockie is also a scientist and a member of the New Zealand Skeptics society and continues Kennaway's attacks on religion as an enemy of freedom. During the 1980s and 1990s he often represented the neo-liberal reforms of both the Labour and National governments as scenes of religious reform and persecution. Later, the rise of militant Islam and the return of political Christianity were likewise attacked, while the rise of New Age thinking was symbolized as the desperate, delusional remedies of the poor and uneducated (see Figure 8).

\section{What religious cartoons reveal}

If such cartoons are 'an editorial in pictures' then what we learn from them is that New Zealand continues to be deeply troubled by religion, and especially by religion seeking to participate in any form in the wider society. What cartoons allow us to express is, in the words of Richard Slotkin, a type of 'definition by repudiation'. ${ }^{59}$ For via their response to the religious cartoon New Zealanders self-identify - as participatory readers - against what we

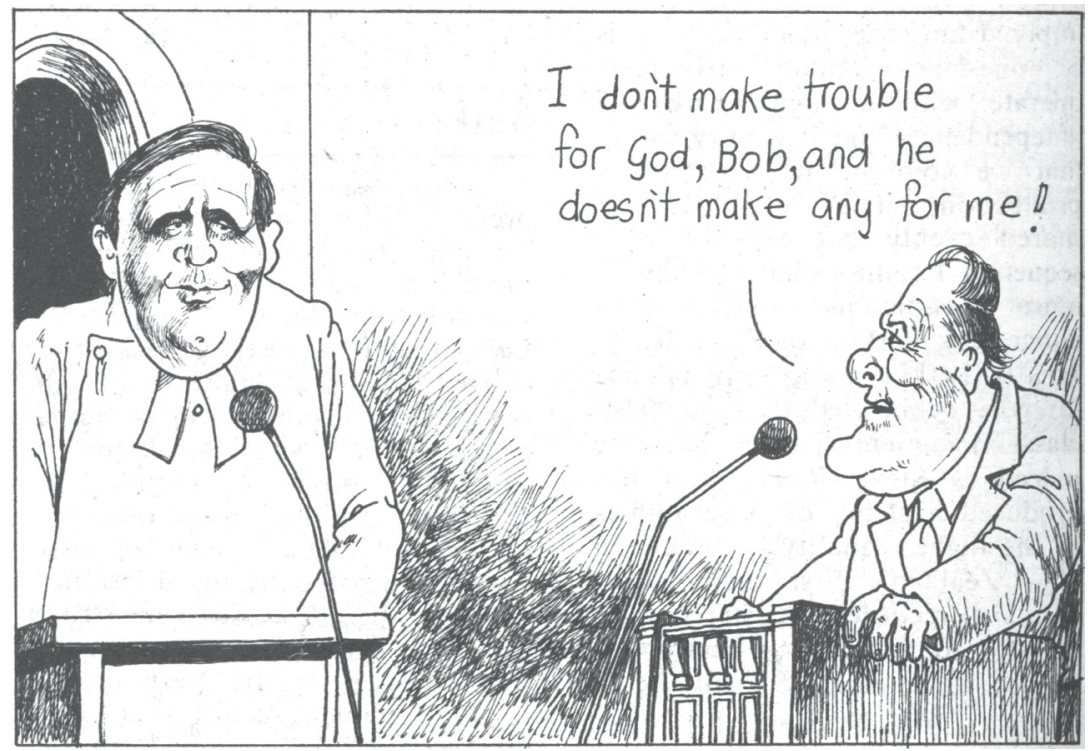

Figure 9: Tom Scott, Listener, 24 December 1977. 


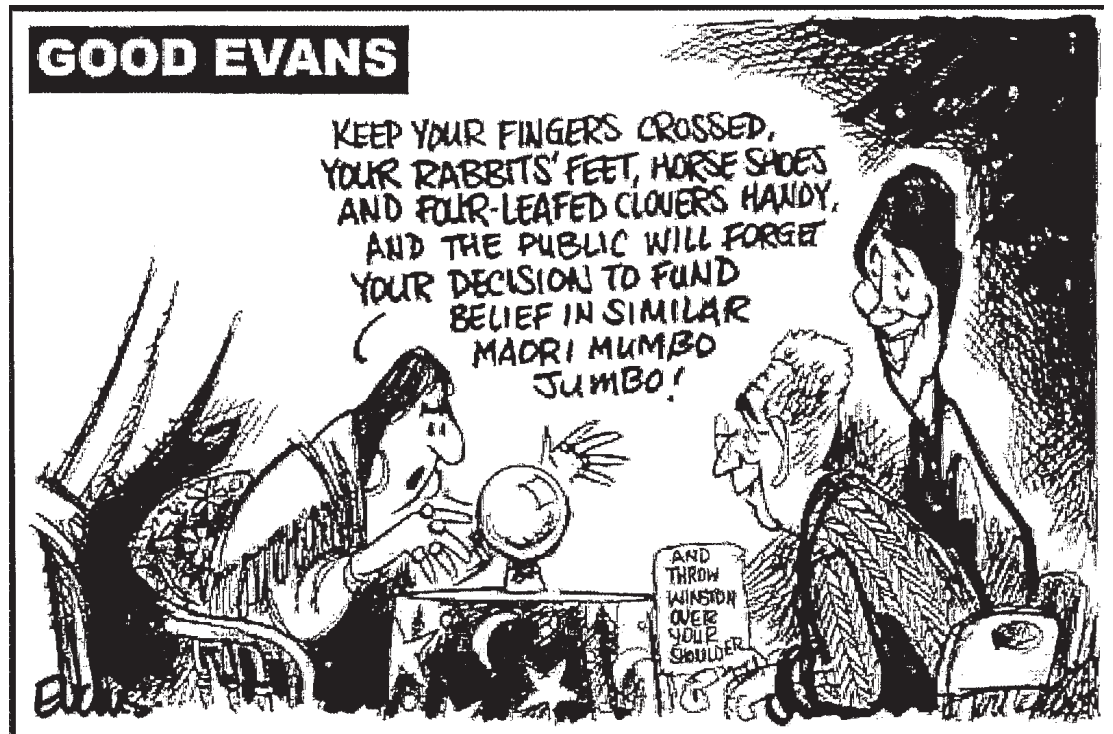

\section{Maori Mumbo Jumbo}

26. Jan 06

Figure 10: Malcolm Evans, 2006.

2xace navers...

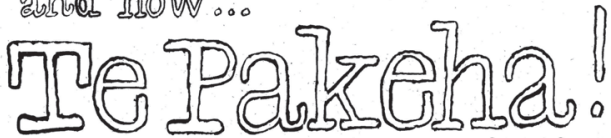

Homage to the ancestral treasures and Gods of the Pakeha.

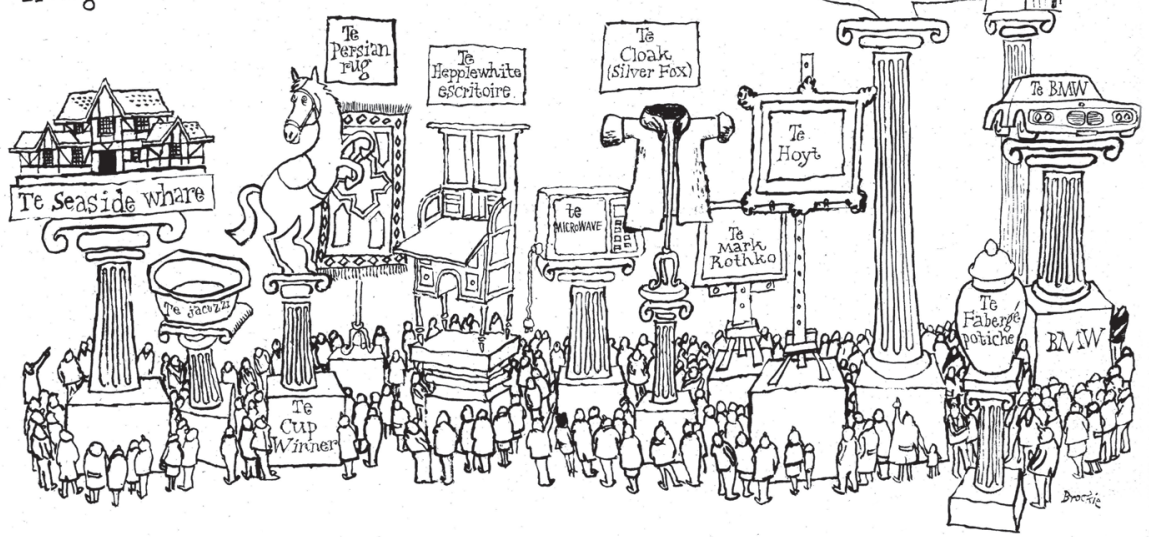

Figure 11: Bob Brockie, National Business Review, 22 August 1986. 
believe we are not: religious, religiously political, gullible, conservative, conformist and materialistic.

Yet if we consider the vitriol heaped on Brian Tamaki, the number of cartoons that attack the leader of a small (7000 member), politically active church, we need to reconsider why. As Lindsay and Hernan note in their analysis of religion in American cartoons, most cartoonists represent positions in line with the cultural left, and so we find a viable and focused target in the New Christian right. ${ }^{60}$

The view is either that religion has no place in the modern world, or should retreat back behind the demarcations positioned and patrolled by liberal, secular society and become acceptable - or at least tolerable by keeping out of politics, demonstrating tolerance for other views and faiths, and not exist within any commodified form of religious experience or institution. Tom Scott neatly summarized this position in his cartoon of Prime Minister Robert Muldoon's rebuke to 'telly-vicar' Bob Lowe (Figure 9).

Yet what is apparent via New Zealand editorial cartoons, is that while we might consider ourselves a secular society, we are afraid of religion and its possibilities. This is especially so with the response to Maori spirituality, and its various expressions of an alternative cultural and political hermeneutic - from Taniwhas to Tamaki (Figure 10). Yet, what does the European population have that can claim to be an alternative? For the spiritual underpinnings of the Maori renaissance and the cultural weight of the 1984 Te Maori exhibition began to raise questions as to the foundations of much of Pakeha culture (Figure 11).

\section{Conclusion}

If we consider that a shared conceptual language is required for cartoons to 'work', then the continued existence of the religious cartoon signals that we are not yet as secular as we might suppose. There is still the ability to read, interpret and re-assess religion in our society, as demonstrated by these cartoons. They present to us what we continue to consider irrational and problematic, whether it is the seasonal cartoons critiquing archaic Easter trading laws or the continual perception that sport in some way is our local, irrational religion, our opiate of the masses.

These cartoons are the first step in compiling a cartoon history of religion in New Zealand. They present us with a rich source of historical and cultural scholarship, not only on religion but also a differing perspective on New Zealand society and culture, its prejudices, assumptions and beliefs - or lack of them. The one theme consistent throughout is that we believe religion and politics should not mix - especially in the public sphere. In short, the cartoon history of religion in New Zealand is a reminder of the necessity 


\section{for religion as the point of definition for a secular society. ${ }^{61}$ This in turn raises this question: when we become indifferent to religion do we stop being secular?}

Figures reproduced by permission

1 David Low, Ye Madde Designer, London, 1935, p.34.

2 Oliver Duff, New Zealand Now, Wellington, 1941, p.38.

3 Ingvild Saelid Gilhus, Laughing Gods, Weeping Virgins. Laughter in the History of Religion, London, 1997, p.103 (ref. to Bakhtin: Rabelais and his World).

4 See William Hoverd, 'No Longer a Christian Country? - Religious Demographic Change in New Zealand 1966-2006,' New Zealand Sociology, 23, 1 (2008), pp.41-65.

5 The two most prominent being the Ratana and Ringatu Churches; the former associated with the twentieth-century prophet Wiremu Ratana and the latter with the nineteenthcentury chief and prophet Te Kooti. Running through Maori society is the concept of Wairua (spirit) which enables a complex mix of syncretism to exist up to the highest levels of Maori Christianity. Wairua is linked to tribal history and tribal land, Maori identifying themselves collectively as tangata whenua or people of the land. In later years, European New Zealanders have also attempted (to various degrees of success) to incorporate and appropriate claims of Wairua and identification with the land.

For a recent discussion on contemporary New Zealand spiritual identity see the essays and poems collected in the longest-running New Zealand literary-cultural journal Landfall: Paul Morris and Mike Grimshaw, eds, Landfall 215: Waiting for Godzone, (May 2008).

6 Theology is also studied in seminaries, and more predominantly in what are termed Bible colleges, which are non-denominational, protestant evangelical and fundamentalist in focus and theology.

7 The issue as to whether New Zealand is modern, postmodern, late modern or indeed soft-modern is beyond the scope of this particular essay. The challenge laid down by Leonard Wilcox in 1985 regarding the postmodernism or otherwise of New Zealand has yet to be properly engaged with. There may be postmodern elements, but any attempt to apply a postmodern discourse and evaluation across New Zealand culture and society will continue to encounter Wilcox's paradox of the continual linking of cultural nationalism with anti-modernist bias in a country still based on pastoral industry. The term modern is therefore used in the most general sense, as that of a western, democratic society existing in the early twenty-first century. I am currently initiating a research project on antimodernism in New Zealand society and self-identity. See Leonard Wilcox, 'More Versions of the Pastoral: Postmodernism in the New Zealand Context', Journal of Popular Culture, 19, 2 (Fall 1985), pp.107-120.

8 The rapid decline in the once-dominant Protestant denominations means that there is a distinct possibility that within a decade Catholicism will be the dominant religious identity in New Zealand. As Protestant identification has continued to decline over the past century, Catholicism has remained remarkably stable, hovering around $14 \%$ of the population.

9 See Peter L. Berger, ed., The Desecularization of the World: Resurgent Religion and World Politics, Washington, D.C., 1999.

10 See Russell T. McCutcheon, The Discipline of Religion, London, 2003.

11 See Tomoko Masuzawa, The Invention of World Religions, or, How European Universalism was Preserved in the Language of Pluralism, Chicago, 2005. 
12 Jonathan Z. Smith, “"Religion” and "Religious Studies": No Difference at All,' Soundings, 71, 2-3 (1988), p.233.

13 Jonathan Z. Smith in Charles E. Winquist, The Surface of the Deep, Aurora, Col., 2003, p.183 (Orig. Smith, Imagining Religion. From Babylon to Jonestown, Chicago, 1988, p.104).

14 Winquist, The Surface of the Deep, p.183.

15 Graham Ward, True Religion, Oxford, 2003, p.viii.

16 Russell T. McCutcheon, “"They Licked the Platter Clean”: On the Co-Dependency of the Religious and the Secular', Method and Theory in the Study of Religion, 19 (2007), p.197.

17 For a comprehensive overview see W.A. Coupe, 'Political and Religious Cartoons of the Thirty Years' War', Journal of the Warburg and Courtauld Institutes, 25, 1-2 (Jan-Jun 1962), pp.65-86.

18 Sir Gordon Minhinnick, 'Introduction' in Ian F. Grant, The Unauthorized Version. A Cartoon History of New Zealand, Auckland, 1980, (revised edition 1987), p.2.

19 I first came across this in Jean Danielou, 'Christianity as a Missionary Religion' in Arnold Toynbee, ed., The Crucible of Christianity, London, 1969, p.295. There are many (over 4,500) easily accessible internet sites that present and discuss this graffito.

20 Ed Ross, 'The Representation of Immigrants and Immigration in UK Political Cartoon from 1968 to 2005', International Journal of Comic Art, 8, 2 (Fall 2006), p.303.

21 Richard Reeves, 'Introduction' in Nancy King et al., A Cartoon History of United States Foreign Policy, From 1945 to the Present, New York, 1991, p.ix.

22 Roy Douglas, Liam Harte and Jim O'Hara, Drawing Conclusions. A Cartoon History of Anglo-Irish Relations 1798-1998, Belfast, 1998, p.2.

23 Dylan Horrocks, 'A Letter from Hicksville. Why I love New Zealand Comics', in D. Horrocks, ed., nga Pakiwaituhi o Aotearoa, Maretai Beach, Auckland, 1998 [unpaginated exhibition catalogue].

24 John Geipel, The Cartoon. A Short History of Graphic Comedy and Satire, Newton Abbot, Devon, 1972, p.9.

25 Lawrence H. Streicher, 'On a Theory of Political Caricature', Comparative Studies in Society and History, 9, 4 (July 1967), p.431.

26 Ibid., p.432.

27 John A. Lent, 'New Zealand - Exporter of mainstream cartoonists, haven for Alternative Comics', International Journal of Comic Art, 4, 1 (Spring 2002), p.170.

28 Low's statement (from Ye Madde Designer) is repeated by Lent, 'New Zealand - Exporter of Mainstream Cartoonists', p.202.

29 Thomas Milton Kemnitz, 'The Cartoon as a Historical Source', Journal of Interdisciplinary History, 4, 1 (Summer 1973), p.86.

30 Grant's text was revised and updated in 1987. Grant later published Between the Lines: A Cartoon History of New Zealand Political and Social History 1906-2005, Wellington, 2005.

31 For more details see, http://www.cartoons.org.nz/other_pages/publications/publications .htm

32 For example, exhibitions/collections to do with Maori, the history of Pasifika people in New Zealand, New Zealand at war, farming, the neo-liberal turn. The cartoon archive site notes that it had presented 13 exhibitions and printed five books by the end of 2005 .

33 Neil Cohn, "Un-defining "Comics": Separating the Cultural from the Structural in Comics', International Journal of Comic Art, 7, 2 (Fall/Winter, 2005), p.241. 


\section{Journal of New Zealand Studies}

34 It is important to note that Belich and Wevers have recently called for more research and discussion on (amongst many areas) the roles of humour and religion in constructing cultural identities of New Zealanders. See James Belich and Lydia Wevers, 'Understanding New Zealand Cultural Identities', Discussion paper prepared by the Stout Research Centre for New Zealand Studies, Victoria University of Wellington, for the Ministry of Culture and Heritage, 2008, http//www.victoria.ac.nz/stout-centre/research/discussion -paper.aspx.

35 Paul Tillich, On The Boundary, London, 1967, pp.69-70.

36 Grace Davie, Religion in Britain since 1945: Believing but not Belonging, Oxford, 1994.

37 For an overview see Patrick Day, The Making of the New Zealand Press: a Study of the Organizational and Political Concerns of New Zealand Newspaper Controllers, 1840-1880, Wellington, 1990.

38 See John Stenhouse, 'Religion, Politics and the New Zealand Wars, 1860-1892', in Rex Ahdar and John Stenhouse, eds, God and Government: the New Zealand Experience, Dunedin, 2000.

39 See Matthew 26:14-16; Mark 14:10-11, Luke 22:3-6.

40 Taranaki Punch, 1, 5 (19 December 1861), p.4.

41 Auckland Punch, 1 (November 141868 to May 8 1869), p.133.

42 There are differing views on the impact of Lloyd Geering on New Zealand Christianity and society. For an overview see Paul Morris and Mike Grimshaw, eds, The Lloyd Geering Reader. Prophet of Modernity, Wellington, 2007. For a response that is more critical from a (largely) evangelical Christian perspective, see Raymond Pelly and Peter Stuart, eds, A Religious Atheist? Critical essays on the Work of Lloyd Geering, Dunedin, 2006.

43 For a good introduction see Peter Lineham, 'Wanna be in my Gang? A New Style of Pentecostalism is Emerging in New Zealand', New Zealand Listener, 195, 3357, (11-17 September 2004), pp.23-24.

44 For a comprehensive overview see Andrew Cutler, 'Intellectual Sprouts, Tomorrow magazine 1934-1940: A Cultural, Intellectual and Political History', MA thesis, Canterbury University, 1989. See also Stephen Hamilton, 'New Zealand English Language Periodicals of Literary Interest Active 1920s-1960s', PhD thesis, Auckland University, 1996, which provides a comprehensive account of Tomorrow and its contents. For a different perspective, see Rachel Barrowman, A Popular Vision. The Arts and the Left in New Zealand 1930-1950, Wellington, 1991. Barrowman positions Tomorrow in a wider cultural discussion.

45 H.Winston Rhodes, Kennaway Henderson. Artist, Editor and Radical, Christchurch, 1988, p.15.

46 Ibid., p.17.

47 "Kennaway" was Henderson's public nom-de-plume.

48 Rhodes in Landfall states, 'He was an Edwardian, of the past but not in it, an old fashioned radical who without loss of integrity adapted himself to the world of the thirties and later.' H. Winston Rhodes, 'Kennaway Henderson and "Tomorrow", Landfall, 54 (June 1960), p.80.

49 Rhodes, Kennaway Henderson, p.14.

50 Ibid., p.37.

51 Ibid., pp.18-21.

52 Ibid., p.27. Sinclaire had attended Auckland Grammar with Mulgan. 


\section{Bishops, Boozers, Bretheren and Burkas}

53 Rhodes, Kennaway Henderson, p.36. Rhodes notes that Low wrote to him that 'It was my dear old friend, Kennaway, who converted me from a religious Methodist biblepuncher to a sincere socialist which I believe I am today'. While Low fails to mention Kennaway in his autobiography, he did contribute an enthusiastic endorsement as the Foreword to Kennaway's book, Cartoons from Tomorrow, Christchurch, 1942.

54 H.Winston Rhodes, Frederick Sinclaire. A Memoir, Christchurch, 1984, p.116.

55 Rhodes states that '. . . warned by the Fraser government, printers refused to print. There was no ban, no suppression, no charge; but the paper could not be published. It died with a bang, not a whimper; and Kennaway's work was finished.' Rhodes, 'Kennaway Henderson and "Tomorrow", p.181.

56 Kennaway's infamous cartoon compared the autocratic and unpopular Cabinet Minster Robert Semple to Adolf Hitler.

57 John A. Lee, 'Psycho Pathology in Politics', Tomorrow (6 December 1939), pp.75-77.

58 Denis Glover, 'Back pages from Tomorrow', Rostrum (August 1940), p.29.

59 Richard Slotkin, Regeneration Through Violence. The Mythology of the American Frontier 1600-1860. Middletown, Conn., 1973, p.22.

60 D.B. Lindsey and J. Heeren, 'Where the Sacred meets the Profane: Religion in the Comic Pages', Review of Religious Research, 34, 1 (September 1992), p.71.

61 See E. Mendeita, ed., The Frankfurt School on Religion, New York, Routledge, 2005; also see Talal Asad, Formations of the Secular: Christianity, Islam, Modernity, Stanford, CA, 2003. 
Journal of New Zealand Studies 